\title{
Money, Religion, and Symbolic Exchange in Winter Sleep
}

Yes! If one thinks about it, you know, looks into it and analyses all this hotchpotch, if you will allow me to call it so, it's not life but more like a fire in a theatre! (Chekhov 2000)

'This isn't a life', complains one of the characters in Winter Sleep, 'it's a fire scene in a stage act'. For all the snow, ice and wind, which frame its spectacular scenes, Winter Sleep is a stunning study of fire. Thus in the film all morality, all sociality and all economy are destined to disappear in an unforgiving spectacle of fire. This route to hell is paved with acknowledged inspiration from a Chekhov story, The Wife, which depicts the 'simple and not strained, but cold, empty, and dreary' relations between an estranged couple living under the same roof (Chekhov 2000). In the film, as in Chekhov's story, the focus is on how sociality is burned down and the characters hit the bottom. Indeed, the film's success is grounded in its ability to portray volcanic eruptions underneath ice, to reveal the fire under the snow.

Winter Sleep is the latest film from an inventive and challenging director with international success. Here I critically engage with it from a social theoretical point of view, focusing on its key theme, religion, and its maneuvers that have diagnostic value for social and cultural analysis. 


\section{Money, debt and symbolic exchange}

Winter Sleep's main protagonist, Aydın, is a graying former actor who moved from Istanbul to Cappadocia after retiring. He runs a hotel, Hotel Othello, which he has inherited from his family together with other property he rents out. His social network is rich and powerful in comparison to the local peasants. He likes giving the impression of being a benevolent landlord but does not hesitate to exercise his power to collect rents. At the same time he has intellectual ambitions (his name 'aydın' means enlighetened in Turkish). He publishes articles in a local newspaper. 'I'm writing a book, too.... History of Turkish Theatre.'

We first meet him on a cold, snowy day, wandering in the Cappadocian landscape. He enters his hotel, chats with a customer, and walks to the window to look out. The camera approaches him from behind, focusing on his head, as if we were entering his mind. At this moment the title of the film appears on the screen. Winter Sleep is a film on ideas. It presents many philosophical ideas through conceptually dense, extravagantly analytic scenes. It is no exaggeration to say that it is 'unabashed essay cinema' (Lodge 2014).

Aydın is surrounded by other people, other ideas, and he gradually discovers that 'Hell isother people!' (Sartre 1944) Indeed, most other characters in the film despise him. Especially the two other main protagonists, the two women he lives with: his middle-aged sister (Necla) and his young wife (Nihal). Necla, a recently-divorced grumpy woman, is a caring sister but slowly turns into a harsh critique of Aydın's pretentious intellectual mediocrity. Nihal is unhappy about her life, contemplating divorce. She finds refuge in charity work, for which she needs Aydın's money, for which she pays with her freedom. 'Do you know how donating even a little of someone else's money feels?' 
The first episode: Aydın must obtain a horse for the hotel. With his right-hand man Hidayet's help he finds a horse keeper who promises to catch for him a wild horse. Then they drive to some tenants to collect rents. On the way Hidayet stops to buy things. Alone in the car, half bored, Aydın catches the angry gaze of a boy looking at him. He shrugs, unable to bestow any meaning in it. On moving again Aydın asks Hidayet: 'Did the other one pay [the rent] after the warning?' 'No. Nothing. The lawyer says we could evict him in two months.' 'How? The law protects the tenants.' 'Well, Mr Aydın, there are actually lots of things to do.' Hidayet is prepared to use force and violence to make the tenants pay.

Hereby the film confronts the viewer with the 'banality of evil' (Arendt 1992). No doubt, one cannot say that Aydın is an evil person. But for evil to occur you don't need evil people. Herein lies Hidayet's (and Aydın's lawyers') crucial function in the film: adiaphorization, or, moral neutralization. Thanks to them Aydın can engage with the social world without recognizing his own active role in its production. In a capitalist society, after all, sociality is dominated by the logic of exchange and thus morality ceases to be a register for reflection. Ultimately, money makes difficult the 'existence of values as such' (Simmel 1978: 255). Capitalism is a world without values. It leaves no other bond between people than naked self-interest, drowning everything else in the 'icy water' of exchange value (Marx and Engels 1948).

Suddenly Aydın and Hidayet hear a noise: the passenger window is shattered by a stone. Hidayet jumps out of the car to catch the boy who has thrown the stone. Trying to escape, the boy falls in the icy waters of the stream across the road. The boy - the same boy who was looking at Aydın angrily in the previous scene - turns out to be the son of a tenant.

This scene is rich in symbolism because the cracked window is a sign of what is to come. Hence the name of the boy: İlyas, the Turkish equivalent of Elijah/Elias, meaning the messiah. To 
appreciate the significance of this scene we must bear in mind the distinction between the linear time of chronology and kairos, the time of the messianic event. Kairos is about 'seizing' chronos, the moment of an untimely intervention (Agamben 2005: 69). And as such, there is a promise involved in it, the promise of the new. Importantly, however, this promise is an 'absolutely undetermined messianic hope', that is, its content is not determined by or reducible to religious experience (Derrida 1994: 81). In this sense, the stone cast by İlyas is a stand-in for hope in the film (see also Seyirci 2014).

'Best get him home quick before he catches cold'. So Aydın and Hidayet go to the boy's home to demand the repair money for the passenger window as well as the rent. While Aydın sits in the car Hidayet knocks on the door. İlyas's father, İsmail, opens the door. 'Your kid fell in the water. We brought him back quick' 'Where, how?' 'Near Issız. He slipped jumping the stream and got wet.' 'What was he doing there?' 'He was hiding, waiting for our car. He threw a stone and broke our window.' İsmail calls his son. 'Did you throw the stone, son?' The boy nods. İsmail slaps him in the face. 'Go now.' Aydın is watching them from the car. 'How's that? Happy? Is that all right now? Feel better? A slap for a broken window. Is that enough for you two? Or should I call him back for some more?'

The sacrificial slapping here has no logic in the context of money exchange. If Aydın's wealth is defined by money as an abstract equivalent, İsmail's sacrifice is a reminder, or rather a rupture, with that economic rationality. Winter Sleep is hinting at that there remain symbolic forces that are still operational within commodified social relations.

At this moment Hamdi, İsmail's younger brother who is also the imam (the local priest) of the village, arrives. 'What's all this, İsmail?' 'So they're here to make us pay', İsmail says. Hidayet protests: 'Did I say that? Didn't I say we brought him home so he wouldn't get sick?' 'Cut it 
out. You took our fridge and TV for a lousy rent. Isn't that enough? Now you're hassling a kid?' The argument flares up, İsmail attacks Hidayet. Still watching at a distance, Aydın is frightened and calls Hidayet to the car. Before they leave, Hamdi comes to them. 'Hidayet, I'm really sorry. I'm as shocked as you. I don't know what to say.' Then, looking at Aydın, he continues: 'Well... the window's broken and we'll pay for it. We'll pay the rent as soon we can, too. We haven't forgotten.... But we're having a hard time.' Hidayet intervenes. 'For God's sake, Hamdi, drop that talk. We didn't say anything for months.' 'OK, Hidayet, come on,' says Aydın. Hamdi is eager to go on: 'But sending a debt collector so suddenly, is that right? You could have talked to us first.' 'Come on, Hidayet,' repeats Aydın, now visibly annoyed. Aydın and Hidayet leave. Hamdi is left behind, heading for his home: 'Bastard. Son of a bitch.'

Notably, debt is an uneven relation: even though the relationship between the creditor and the debtor is a 'contractual' relationship, there is always an asymmetry of power involved in it (Nietzsche 1996: 45). Money, then, is not merely a means of exchange but a significant component of practices that constitute power. In market exchange money functions merely as a measure of value. But in the form of capital it functions as a measure of the value of values. Hence the power of abstract capital (value producing more value) is not reducible to its market function, to exchange. In this sense, insofar as it is linked to credit (credos), one can say that capitalism (does not only level but also) creates beliefs and desires, forms a moral subjectivity. As such, debt becomes a factor of sociality, that is, a dispositif, a technique which imposes a particular conduct, a model of truth and normality on sociality by defining power relations. Consequently, abstract money turns into a source of systemic violence that pushes everything into the 'icy waters' of its value form. This is the background against which the events unfold in Winter Sleep. 


\section{Vanity, mediocrity and religion}

Back at home, Aydın is in his own room, writing. Enter his sister Necla. 'Are you writing your column?' 'I'm trying to.' 'By the way, I read last week's. I liked it.' 'Which one do you mean?' 'Urban ugliness in Anatolia. Aesthetic deprivation and so on.' 'Right.' 'Bravo. How do you come up with interesting ideas every week?' Aydın brings the topic to his tenant Hamdi. 'Who is he? Do I know him?' 'No, you wouldn't. [...] Just a crooked, shabby guy.' He continues: 'I don't know... Shouldn't men of God be a model to the public? Especially in rural areas. Perhaps I should write about that next week?' Necla is supportive but thinks he should write in a bigger paper. 'I don't agree with you, my dear Necla. On the contrary. Sometimes I receive letters...' His sister interrupts him, the topic changes.

Aydın gets another opportunity to open the same topic when his friend Suavi visits him. Aydın shows him a letter from a surrounding village, written by a 'great admirer' of him, obviously a woman. The letter is asking for charity to build a technical school for girls in a poor village. But just before listening to his friend's opinion Aydın remembers that 'Nihal loves charity like this. Should we call her as well?' Nihal joins them as well. Suavi's reaction to the letter is 'don't know'. Nihal's is straightforward: 'We've been collecting donations for this for a long time now. But it never attracted your attention. So I don't understand your sudden charity.'

Aydın's charity is rooted in his vanity. Hamdi lays it bare when he visits Aydın in order to apologize for both İlyas and İsmail's behavior (İlyas ‘feels really bad about it. He wants to come over and kiss your hand for forgiveness'; İsmail 'just came out of prison, he hasn't sorted himself out yet. Nobody gives him a job.') Aydın only responds to the smell of Hamdi's feet: 
'Sorry, just a minute. It's a bit stuffy in here. If you don't mind... I'll open a window.' 'So, Mr Aydin, if you could just step in to stop the eviction... We will sort something out as soon as possible. We really don't want to lose the house.' Here we see the limit of Aydin's charity: 'I mean... There's Hidayet and the lawyers. You don't need to come to me.' Hamdi leaves. Aydın returns to his article on religion inspired by Hamdi.

In a country with a 99\% Muslim population, don't the people deserve men of God who are cultivated, neat, whose very presence is reassuring? The weekly sermon prepared by our imams, from their reading, will be heard with pleasure and admiration and will elevate the people. Islam is a religion of civilisation and high culture.

'How's that?', Aydın asks Necla. 'Fine.' 'It's not too harsh?' 'No.' 'Nothing that might be misunderstood?' 'No. You don't say anything about religion itself. You talk about the practices of those who apply it.' 'And I also say Islam is a religion of high culture. Of course. I don't really care for these things. But you know it's delicate. But the guy annoys me so much, I can't stop myself writing. So he managed to become the subject of an article. With his shabbiness, slyness, vagueness...'

So what kind of an intellectual is Aydın? For him thinking is a matter of recognition. But 'only values which are already current, only accepted values, give criteria of recognition' (Deleuze 1983: 81). The new, on the other hand, always brings forth dispute. Intellectual thought always involves disagreement, which is, above all, a disagreement on consensus, on recognized values (Rancière 2010: 144). The true target of intellectual thought, in other words, is not playing a given game, indulging in its officially recognized transgressions, but challenging the game itself. Such thought necessitates a process of separation, of dis-identification, vis-à-vis a given 
framework of the sensible with a view to opening up a space for what can be said, seen and thought otherwise (Ibid 212).

A critique of Aydın's position along similar lines is articulated later in the film by Nejla, when, in an argument, she reveals to Aydin that 'on a second reading' she found his articles 'harmless.' Aydın's critique is only mediocre. 'This soppy romanticism. This naive, unconvincing selfbelief. Takes no risks, for one thing. It looks like the writer adopts positive values accepted by all, just to endear himself.' The same goes for Aydın's article on religion. 'You found a victim and you're making the most of it. Stop harassing the poor man.'

In a country polarized by Islamic governance, experimenting with varieties of Islamic neoliberalism and neo-liberal Islamism, Hamdi is too easy a target to articulate a critique of religion. More importantly, Aydın is looking for religion in the wrong place. In today's world, after all, capitalism has become a religion and religion has become capitalism. Henceforth we should look for religion not in theological categories but in capitalism. Let us, to discuss this, revisit the essential link between capitalism and religion.

Weber's discussion of the 'spirit' of capitalism is well-known in this context. Since capitalism is a world without value, an inherently nihilistic system, it is constantly in need of moral justification, which can only come to it from outside. This external source is the Protestant ethic, which originally provided capitalism with a religious basis, with a 'spirit', although, according to Weber, the pact between capitalism and Protestantism has later weakened to the point that 'victorious capitalism ... needs its support no longer' (Weber 2003: 181-2). Secularization brings with it disenchantment. Contra Weber, however, theology persists as an active force in modern economy for capitalism and Christianity are structurally linked together. 
What links them together is articulated in social theory through the notion of guilt or debt. Seen in this prism, capitalism has not only found support in religion but it emanates from religion (Benjamin 1996). Capitalism is a cult religion which does not expiate but produces guilt (Ibid 288-9). Indeed, it is through the mechanism of guilt (debt, credit) that value begets surplusvalue, a process that resembles a god's self-generation out of nothing (Hamacher 2002: 92). Thus, in Marx, the law of value functions as an abstract law that governs the relations of equivalence among commodities, as a transcendent moment within the immanent relations of equivalence. 'Money is therefore the god among commodities' (Marx 1993: 221). The paradox here consists in the movement through which the abstract value becomes totally value-free: abstract capital that seeks out further accumulation of capital whenever, wherever, by whatever means. Ultimately, therefore, the concept of (exchange) value can say nothing on value. It is in this sense that the world of capitalism is essentially a world without value. However, this cynicism must not be mistaken as the absence of a religio-moral dimension in capitalist sociality. For such cynicism is often coupled with the sacralization of capital (Deleuze and Guattari 1983: 225). Capitalism posits an infinite debt to capital; everything appears to emanate from and return to capital. Thus most people today can imagine the end of the world but not that of capitalism (Žižek 2009: 78).

Already Spinoza emphasizes that money can appear as 'cause', that is, as God: money provides a short-cut to everything and therefore the multitude 'can scarcely imagine any kind of pleasure unless it is accompanied with the idea of money as the cause' (Spinoza 1993: 192). Religion, Feuerbach adds, takes over the best qualities of humans and allocates them to God, affirming in God what is negated in man (Feuerbach 1989: 27). Hence the paradox of religious alienation: the more God is glorified or valued, the more human life is depreciated and devalued. Marx repeats the same logic in 1844 Manuscripts regarding capital as a source of economic 
alienation: the more wealth the workers produce in capitalism the poorer they become (Marx 2007: 119). Just as religion captures what is profane and sacralizes it through glorification, capitalism captures the commons and commodifies them for display in the spectacle. Not surprisingly, therefore, the glorification of capital parallels the glorification of God. In both cases, 'glorification is ... what produces glory' (Agamben 2011: 216, 227). And in both cases, what is at stake is human life, which is, originally, inoperative, that is, without a utilitarian purpose (Ibid 245-6). What religion does is to capture this inoperativity and inscribe it in a religious sphere, to sacralize it, only to partially return it in the form of the 'Sabbath' when all 'work', all economy, ceases to exist and everything falls back upon inoperativity. What capitalism does is to capture the multitude's inoperativity, its creative freedom, and inscribe it in a utilitarian sphere, only to partially return it as permitted freedom, as 'holiday', which is the main promise of work in capitalism. A post-governmental promise, in which work (hell) is replaced by play (paradise).

\section{Not resisting evil}

Aydin is not the only one speculating on religion in the film. Necla, too, is immersed in the topic. In a conversation she asks Aydın what 'not resisting evil' means to him. But Aydın's 'logical' answer (remaining indifferent to evil) is not satisfactory to her. Next day she opens the same topic during the breakfast.

I still feel... we're fooling ourselves when we're fighting evil. [...] Instead of struggling against evil, why not do the exact opposite? Say you don't want a painting to be stolen. It's maybe better to hand it to the thief. Maybe it's a better solution. 
This is of course a clear reference to the Bible: 'Ye have heard that it hath been said, An eye for an eye, and a tooth for a tooth: But I say unto you, That ye resist not evil: but who soever shall smite thee on thy right cheek, turn to him the other also' (Matthew 5:38 and 39). If someone does you evil, you must not respond in kind but put a distance to it; doing otherwise is participating in evil, which can only lead to its metastases.

So Aydın's vanity is confronted with Necla's Christian ethics. Taken to its logical limits, Necla implies, 'Resist not evil' would lead to a sociality grounded in forgiveness. Not responded in kind, the evildoers would potentially be ashamed and feel reomorse. Unsurprisingly, however, Aydın is not capable of grasping the theological detail: 'What a ridiculous idea! Should we allow mass murders because some killers could regret it? Even soaps don't produce such nonsense.' Certainly, Necla's ethics is prone to problems. Why, after all, should one assume in social situations characterized by conflict that one's opponents/enemies will refrain from using their force, from doing what they can do? Such an assumption (already ridiculed by Nietzsche in the image of a bird of prey that can stop preying on lambs) is itself a moralistic position for it essentially reduces power to something that can be separated from what it can do. In this perspective, Necla's Christian ethics boils down to normative imagining, to idealism.

Nihal intervenes with an interesting remark: 'To be honest... I don't quite grasp it. Where does this need come from? Why do you feel like this?' Here Nihal points out the immoral core of Necla's morality. There can be no inherently moral phenomenon but only a moral evaluation of certain phenomena as moral from a certain perspective; morality is necessarily a perspective that coincides with the moralist's conditions of life and his judgments as to these conditions (Nietzsche 1967: 148-9). The essence of Necla's argument lies in its being a perspective. What 
drives her is an active force, a 'need', even though this force seems to be latent (see Nietzsche 1996: 67, 119).

Necla defends herself: 'It's not a need, just an idea.' At this instant the discussion is interrupted for Hamdi comes once more, this time together with İlyas so that İlyas can apologize to Aydın properly. Aydın is irritated. They are served tea and cookies. Hamdi takes the word: 'Come on now, son, kiss Mr Aydin's hand.' But there is no response from the boy. 'İlyas? Didn't we say we'd go and do this without telling your dad? Don't embarrass me in front of everyone. Come on, son. Kiss Mr Aydin's hand.' 'Fine, then', Aydın reluctantly stretches his hand. 'İlyas, come on. Mr Aydın is waiting.' The boy faints. This fainting/resisting is allegorized in the next scene through the taming of a wild horse (found for Aydın's hotel).

The following day Necla and Nihal have a conversation. Necla is worried that her ex-husband has become an alcoholic. 'But he always drank a lot, didn't he?' 'He did indeed, but... he's been drinking much more since we separated.' Then we realize why Necla 'needs' her philosophy of not resisting evil: 'Sometimes... I can't help thinking we're worse off after splitting up. Him over there in that state, me here miserable.... If I'd overlooked all the evil stuff Necdet did to me, if I hadn't resisted, if I hadn't divorced him, say. If I could have made him face his own evil side. I don't know. I wonder what would've happened if I had acted differently.' 'You mean, if you hadn't resisted all the bad things he did, he would've finally felt ashamed?' 'Yes. Yes. Exactly. You put it well.' Nihal ascertains the idea that not resisting the evil may only make the other feel even more justified.

This is the point at which Necla hits the bottom. First she picks up a fight with Nihal. 'The real reason I'd apologise to Necdet is maybe to get away from all of you and all of this. It's pretty 
clear now.' Then, in another conversation, she spitefully attacks Aydın's mediocrity ('this soppy romanticism...'). 'I can't believe how I left a place like Istanbul and agreed to come and live with you.' Aydın can only say: 'You're bored because you sit around doing nothing. You've really let yourself go. You used to do translations. You stopped even that. Of course you're bored.' 'Maybe I don't know what to do. I've no passion to give me direction. But then, what do you do?' After this scene Necla leaves for Istanbul.

The following scenes depict how Nihal and Aydın hit the bottom. Aydın accidentially learns that Nihal's charity group is having a meeting. He insists on staying (he is jealous of the close relation between Nihal and Levent, a member of the group). But Nihal asks him to leave. 'Listen to me, Aydın, please. We've lived in peace for two years, each to his own affairs. What's suddenly changed? [...] If we start fighting and quarrelling again like we used to, then it's clear I can't stay here.' Aydın replies that he is going anyway; he has decided some time ago to go to Istanbul. He has but one question: 'What have I done to you? Is that you're young, beautiful and would like to live your life? I'm much older than you and you hate me for that? Is that my guilt?' 'I always felt I'm older than you anyway. But you're an unbearable man. You are selfish, spiteful, cynical. That's what you're guilty of.' Finally, Nihal asks Aydın to let her alone in her charity activity. 'Because this is my only consolation. I spent my entire youth fighting with you. Now, thanks to this work, I believe in myself again.'

Hidayet takes Aydın to the railway station. But lacking the determination, he cannot leave. Instead, he decides to visit Suavi.

\section{Burning money}


Before leaving, Aydın makes 'a small donation' to Nihal's organization in a rather demonstrative way. Nihal decides to give this money to Hamdi's family as a gift. Hamdi is surprised. 'But this is a huge amount of money. How can I accept this? There's enough to buy a house. What would people think?' 'Mr Hamdi. No one needs to know. This can stay between you and me.' Nihal's intention is to realize a purely ethical exchange, without the intervention of a third party, of the social. But unexpectedly, in the middle of their conversation, İsmail comes home. He is drunk.

Hamdi explains to him: 'Nihal was worried about İlyas. She came to wish him good health. That's why she came.' But İsmail sees the money on the table: 'What's this?' She thought they might need it, Nihal explains. 'What does Mr Aydın say about it?' 'He doesn't know. He doesn't need to know, either.' İsmail counts the money. 'But all this money... isn't it a bit too much?' Hamdi is both nervous and embarrassed. 'I apologise. He's surprised, too. İsmail, why not go and wash your face or something?' 'No need.' Hamdi goes out of the room to ask İsmail's wife to make tea for the guest. Nihal and İsmail are alone. İsmail continues:

Let's see... if the math is right. Now if this amount is... for little İlyas who risked his life to mend his father's broken pride. And if this is... for the self-sacrificing brother Hamdi who had to go hand-kissing because he looks after five people. And if this is for the drunkard father İsmail who got beaten up in front of his son disgracing himself and his family... There's still some left. If that is for our heroine Mrs Nihal who tries to ease her conscience by doling out charity to those less fortunate than her... then this money is just enough. You got the sums right. A truly kind thought, but... you forgot something, Mrs Nihal. The person in front of you is a filthy drunkard incapable of appreciating all your kindness. 
Nihal is annoyed by İsmail's sarcasm but keeps herself under control, saying nothing, trying to endure the spectacle. İsmail stands up. He throws the money into the fire. Nihal is stunned, unable to say anything, as if she has seen the devil. There is a barely noticeable, bitter smile in İsmail's face. İlyas is peeping through the door. His eyes meet his father's. Next, we see Nihal driving back, crying loudly. We had seen her alone and desparete in her room after her discussion with Aydin, but now, as the meaning she ascribes to her charity is violently questioned, she hits the bottom.

But this fire scene, absolutely the most powerful one in the film, is skillfully left ambivalent so that it opens up for different lines of interpretation. The spectacle İsmail is staging immediately brings to mind the figure of the 'abject hero" (Bernstein 1992), a character that originated already in the carnival, in Saturnalian dialogues, in which the roles of the master and the slave are reversed. Crucially, the structure of the dialogues has a deeply bitter and negative strand that has survived throughout modern times. In contemporary culture the abject hero remains a central figure who refuses to conform to the society which he despises. In this sense İsmail adopts the discourse of the slave in the carnival. For the same reason he seems to have jumped out from Dostoevsky novels (recall the father in Brothers Karamazov who characteristically debases himself in order to debase others around him or the character who burns money in Idiot). I am cynical, but the society around me is more cynical; I am bad, but you are worse. I am a 'filthy drunkard', but you are...

One can perhaps go further along another line of thought. The film indicates that Aydin, Necla and Nihal's world is, for all their references to 'telling the truth', 'facing the truth' and so on, a disenchanted, reified world in which the illusion of truth has disappeared. They are people who 
can do without heaven and hell (although they do not stop talking about religion, debt and guilt). It is as if the 'real world' which religion contrasts to the existing world - the world of appearances - is replaced with a notion of reality constituted on the basis of representation and meaning. But just as religion once turned into a fiction, Aydın's, Necla's, and Nihal's world, too, gradually reveals itself to be a simulacrum suffocated in its own accumulation. The problem with such a world is demonstrated in Nihal's unsuccessful attempt at symbolic exchange, at giving a gift. İsmail's act indicates that a symbolic resolution is no longer possible in a world in which everything has disappeared into the 'icy waters'. It signifies the 'accursed share', the devil's share, which cannot be included within and thus challenges the reality principle of the discontented trio's world. İsmail's world is one that cannot be exchanged in theirs: it has no equivalent anywhere in it. This is the reason why İsmail is ruthlessly sarcastic about Nihal's 'charity' that threatens to turn ethics into a matter of accountancy. Along the same lines, the consequence of burning money is to short-circuit the principle of equivalence regulating Aydın's, Necla's and Nihal's - and at this point we can add Hamdi to the series - world, the illusion of which consists in denying its outside: symbolic exchange. As Baudrillard insisted, a world in which symbolic exchange is not possible can only be destroyed symbolically. Concomitantly, all Aydın's, Necla's, Nihal's and Hamdi's efforts to make their world a meaningful place are annulled by İsmail's single 'nihilistic' act:

Behind the exchange of value and, in a sense, serving as an invisible counterpart to it ... behind the exchange of something, we have, then, always, the exchange of the nothing. (Baudrillard 2001: 7)

The 'nothing', the void created by İsmail's act, is effectively emancipation from the existence as it is defined in the icy waters of the money economy. By the same token, the real catastrophe 
is not - as Nihal's face indicates - throwing the money into fire, but living in a world in which this void is foreclosed, a world dominated by 'rational' exchange alone.

In stark contrast to Necla's attempt at 'not resisting evil', which is reducible to a 'need', İsmail is the only person in the film who truly can speak 'evil', which consists in his insight into symbolic exchange as a challenge to the consensus on economic exchange. This is precisely the antagonistic dimension in İsmail's act which is impossible to grasp for Nihal and the others. Without İsmail's antagonistic, 'evil' intervention, we would be left at the mercy of the forces of the good (Aydın's mediocrity, Necla's Christianity, Nihal's charity, Hamdi's Islam). İsmail's evil act, which is itself a spectacle, an illusion, to be sure, is ultimately what protects us from the good by pushing it towards excess. 'On the symbolic plane, there is only one way to pay back, and that is the counter-gift' (Baudrillard 2005: 171). If it is impossible to give a countergift, which is the case for İsmail, then one can turn the refusal of the gift into a counter-gift. This is what İsmail does. And from the perspective of İlyas, his father's act, which he watches from behind the half-closeed door, is a Manichean gift, a symbol of a world in which everything is antagonistic. (It is well-known that the İsmaili-sect in Islam was heavily influenced by Manicheanism and Gnosticism, the two forerunners of Messianism; see Gibson 2012: 112-125).

Seen in this light, Winter Sleep is a 'fatal' movie that plays at the collapse of the social. It masterfully demonstrates why 'the real is what one must not consent to' (Baudrillard 1987: 69). Herein lies, too, the clue to understand the smile in İsmail's face after throwing the money into fire: for İsmail everything around is a pile of pseudo-events, a farcical flow of empty, chronological time. Like 'hell' described by Benjamin: bare repetition, the eternal recurrence of the same non-events which produce no difference. The only radical act in a world experienced like this can be one that can work as an 'emergency break' (Benjamin 1999: 252- 
4). An event, in which 'time stands still and has come to a stop' (Ibid 254). Hence the horror in Nihal's face on watching money on fire: she cannot grasp what is happening because she is preoccupied with causal, chronological relations between the past (debt) and the present (redeeming the family's debt through charity). The time of İsmail's act, however, is not chronological time. If history repeats itself as farce, if in pseudo-history the tragic reappears as comedy, this is not necessarily a reason for melancholic detachment but rather an occasion for a joyful separation - history has this course 'so that humanity should part with its past cheerfully' (Marx 1975: 179; Agamben 1999: 154). As such, İsmail's act is the ground zero of Winter Sleep.

\section{Fooling about}

In Suavi's place, which Aydın decides to visit instead of going to Istanbul, there emerges another verbal fight between Aydın and Levent (whom Aydın is jealous of). Levent quotes from Richard III: 'Conscience is but a word that cowards use devised at first to keep the strong in awe. Our strong arms be our conscience, swords our law.' Here Aydın is exposed as a nihilist in the Nietzschean sense, as a weak personality hiding behind morality and conscience. He responds with another quote from Shakespeare: 'Our infallible fate is to be deceived in everything we attempt. I make brilliant plans each morning... and fool about all day.' This can be read as a reply to Levent. But it is tempting to read it as a confession as well.

The morning after Aydın returns to the hotel. He sees Nihal but his pride prevents him from telling her what he thinks. Instead, he rehearses: 'I didn't go away. I couldn't. [...] Please, don't ask me to go either. [...] I know very well how terrible or impossible it would be to part from you. Just as I know that you do not love me anymore. I know we can't go back to the old days. 
And there is no need to. Take me with you like a servant, like a slave. And let us continue our life, even if we do it your way. Forgive me.'

This is a final that remains faithful to the ambivalent affective structure of the film: we cannot be certain, as Aydın's facial expression indicates, whether Aydın's thoughts are really decisions or momentary affects that can move into different directions, whether they will be really said to Nihal or remain as inner thoughts (see NB Ceylan in Aytaç et al). At any rate, the scene demarcates the point at which Aydın hits the bottom, which is the unavoidable destiny of all the characters in the film.

But hitting the bottom is a promise, too, a sign of liberation. Thus, when, in the final shot, we see Aydin for the last time, he is noticeably calm. He finally starts to write his book 'History of Turkish Theater'. Life goes on; Aydın might 'fool about' through yet another winter sleep. The film's focus on intellectual life vis-à-vis religion is particularly significant in this regard. Consider Necla's double accusation directed against Aydın's mediocrity:

You know what your problem is? In order not to suffer, you prefer to fool yourself. Yes, that's it. But one has to have the courage to face the truth. If you're looking for something more real, you'll have to be destructive when necessary, dear Aydın. But since you're an actor, you forgot about being real, being yourself. You jump from one personality to another, just like a grasshopper.

Necla couples this critique with another, referring to Aydın's article on religion: 'I should ask what religion, faith, spirituality have to do with you. Have you ever set foot in a mosque? Have you ever prayed so that you can talk about it?' To this Aydın replies: 'Do I have to go to a 
mosque to write about religion?' But this response does not stop Necla: 'You keep saying the imam's feet stink. What's it to you? The man walked $10 \mathrm{~km}$ in this cold. And he had to enter the room with those feet.'

There is a lot going on here. It is of course true that Aydın lacks the courage to face the truth, which he himself indirectly admits in the final scene (the quote from Shakespeare). However, two things are essential to note. First, insofar as 'all the world is a stage', the first part of the accusation is misditected. Not only because there is a close relationship between theater and sociality. More importantly, intellectual production itself is a theatrical activity in the sense that it involves dramatizing (actualizing) abstract (virtual) ideas. Just as every time an actor stages a play differently, thinking involves the creation of difference thorough repetition of ideas (see Deleuze 1994). Likewise, Winter Sleep - a theatrical film from beginning to end - effectively wears the mask of Chekhov (particularly his short stories The Wife and The Excellent People), repeats his themes, but producing a difference (especially by making use of ambivalence and suspense). Therefore, to return to Necla's point, one can say that Aydın's problem is not being an actor - on the contrary, he is too mediocre to have a sustained fidelity to any mask, to any idea.

Second, and more problematical in a political context, Necla associates spirituality with monotheistic religions. Thus setting foot in mosque or church becomes a prerequisite (blackmail?) both for truth telling and for speaking about religion. Consequently, Aydın's question is pertinent (does one have to go to a mosque to write about religion or speak about spirituality?). How can one answer this question, which the film skillfully stirs away for all its focus on religion? To answer this question, it might be useful to revisit Foucault's work on political spirituality. Crucially, 'spirituality' at issue here is neither reducible to religion nor 
religious in its essence. It can be taken as a profane concept that refers to a set of practices that arise when a truth is obscure to the subject. In this sense spirituality is what enables the subject to access truth and to criticize power. Therefore it is grounded in truth-telling, in what the ancient Greeks called parrhesia (see Foucault 2001: 19). Hence the famous image of the Cynic, Diogenes: the dog-like truth teller living in a barrel, insisting that the most important thing in life is freedom of speech, parrhesia. A freedom which must be protected from the influence of wealth and power at any price: 'for if I should be bribed too, there would be none left to rail upon thee' (Shakespeare 1970: 665).

It is in this sense that Aydın is not in a suitable position to engage with truth telling. But what does this have to do with Necla's rhetorical question (whether Aydın has ever prayed...)? Interestingly, Foucault mentions at a certain point the Cynics' 'resemblance to the early Christians' (Foucault 2001: 116). Christians took over from the Cynics the practice of preaching, a form of truth-telling which involves the idea that truth must be told to everyone (Ibid 120). Most importantly, the Cynic asceticism played a decisive role in early Christianity. Foucault's strategy here is obvious: he is historicizing religion. Theology is a phase in history, not an absolute beginning. Then, what is sacralized can be profaned. If parrhesia is captured by religion it can be re-appropriated. With Foucault, therefore, we can imagine a profaned form of political spirituality which is not reducible to revealed religion. The political horizon Winter Sleep depicts seems to be silent in this regard. But it is not completely so. To discuss this let us conlude with focusing on two protagonists in the film, Necla (the Christian) and İlyas (the messicanic stand-in for hope).

\section{Conclusion: globalatinization versus 'messianicity without messianism'}


Is Necla really a Christian? How to explain her Christianity? Derrida's concepts 'autoimmunity' and 'globalatinization' can be useful to discuss this. Insofar as it is an experience of the sacred, of the holy, religion is about purification and immunization, about keeping the sacred 'intact, safe, unscathed' (Derrida 2002: 61). Thus in modernity there appears to be an antagonism between the 'miracle' (religious faith) and the 'machine' (capitalist technoscience). In order to protect itself, to immunize itself, religion seeks to reject capitalism and technology. The paradox, however, is that while reacting antagonistically to the capitalist technoscience, religion also, at the same time, re-affirmatively outbids itself. It appropriates capitalism and science while it rejects them, and thus faith and science, miracle and machine, 'overlap, mingle, contaminate each another without ever merging' (Ibid. 63). Religion's zeal for immunity leads to the loss of immunity. Like redundant 'anti-bodies' that turn against the organism in which they live, religion embodies an auto-immune pathology in relation to technoscience.

The global 'return' of religion today, which also constitutes the social context of Winter Sleep, takes place against the background of this auto-immunity. The globalization of religion can be understood in terms of a 'strange alliance of Christianity, as the experience of death of God, and tele-technoscientific capitalism' (Ibid. 52). The two siblings Necla and Aydın constitute in the film the two sides of this 'strange alliance'.

Derrida calls this auto-immune process which is simultaneously hegemonic and in the process of exhausting itself 'globalatinization' (Ibid.). Globalatinization is an 'essentially Christian' process whose dominant language is Latin in the sense that "whoever speaks religiously or about religion' today remains under its influence (Ibid. 66). Even Judaism and Islam, in a certain sense, speaks Latin. But why is globalatinization in the process of exhausting itself? The return of religion brings with it a 'trivialization' through which religion destroys its own conditions of existence (Vries 2005: 367, 370). But this banalization is not the end of religion. Because the 'sacred' is not the only source of religion. Derrida distinguishes between two sources of 
religion. On the one hand, as already mentioned, religion is grounded in an experience of the sacred, of the holy, which it seeks to immunize against all that which is perceived as 'evil' (Derrida 2002: 42). But this attempt, which is also a promise of salvation, is not the whole story. Religion has another, more significant source, which is grounded in the promise itself but cannot be reduced to the object of promise (salvation, redemption...). Derrida calls this source 'messianicity without messianism', a messianicity which does not depend on any messianism, any Abrahamic religion, and does not follow any revelation. The difference between messianicity and messianism is tantamount to the difference between the virtuality of an event and the actual(ized) event, between the potentiality of revelation - 'revealability' - and the actual revelation (Ibid. 59). As such, as a virtual or abstract faith, messianicity is not reducible to religious faith.

This is why Derrida can argue that within the communist and democratic traditions there is a messianism which is not reducible to religion through any deconstruction. What is irreducible in 'messianism without religion' is an experience of the 'emancipatory promise' (Derrida 1994: 74). A promise, whose effectivity keeps within itself an 'eschatological relation to the to-come of an event and of a singularity, of an alterity that cannot be anticipated' (Ibid. 81). In contrast to religion, therefore, the content of this promise is not determined. The 'alterity' of that which returns in non-religious messianism 'cannot be anticipated'. The absolute difference of the event forecloses the return of the absolute as a religious figure. What is 'to come', the future, remains unpredictable, new. The Last Judgment will not occur. Instead, the messianic return demands a 'messianic opening to what is coming, that is, to the event that cannot be awaited as such, or recognized in advance' (Ibid.). Non-religious messianism is a 'call', a 'promise' of the new, which always comes in the shape of emancipation, justice and peace; a promise independent of the three monotheistic religions, even when they oppose one another, for it holds to the anti-nihilist belief that 'faith without religion' is possible (Derrida 2004). Herein lies the 
significance of İlyas in Winter Sleep: it all starts with his falling into icy waters, all the episodes in the film are connected with him in one way or another, even the most violent act, İsmail's act of burning money, is staged for his gaze, and for all the pseudo-intellectual debating on religion, he is the only stand in for belief and hope in the film.

There are two significant consequences of the link between Illyas and messianicity in this sense. First, it becomes possible to distinguish religion and faith; faith is not reducible to religion just as religion is not necessarily faithful. And second, since messianic faith is a necessary but external condition for religion, it follows that that its religious appropriation (sacralization) is not an unavoidable process. Once again, profanation becomes possible. Another way of saying the same is that religion cannot fully appropriate or exhaust the messianic. The messianic is a virtual possibility, which, for all its repression and trivialization, cannot be eradicated. A real possibility, which persists, always reappears. Its virtuality can always be appropriated by religion, but it cannot exhaust itself in religion. The religious machine can only emerge from this groundless ground. Without the second source, 'there would be neither act of faith, nor promise, nor future...' (Derrida 2002: 57). Indeed, insofar as religion is reduced to its 'sacred' components, it falls back upon the domain of common sense, becomes a 'fetish'. The messianic, in turn, is a break with the fetish, and signifies the opening up of the actual to the virtual.

What the religious machine, or organized religion, seeks is to codify this virtual source as a rule-set. It attempts to formulate a foundationalist, supra-individual or social codex for how individuals must organize their conduct with one another. Thus the religious machine always implies that we can be moral only is, only when we are religious. It invites us to presuppose that, expelled from the Garden of Eden, human beings can only manage their lives if they have a codex to follow: 'morality as obedience to the Law and the recipe for a trouble-free life of conformity' (Bauman 1998: 13). But Winter Sleep demonstrates that even in hell there can be hope and, more interestingly, another way out. 


\section{REFERENCES}

Agamben, G (1999) Potentialities. Collected Essays in Philosophy. Stanford: Stanford University Press.

Agamben, G (2005) The Time That Remains. Stanford: Stanford University Press.

Agamben, G (2011) The Kingdom and the Glory. For a Theological Genealogy of Economy and Government. Stanford: Stanford University Press.

Arendt, H (1992) Eichmann in Jerusalem - A Report on the Banality of Evil, London: Penguin.

Arianrhood, B (2014) 'From Shakespeare to Sartre: Excellence', http://www.imdb.com/title/tt2758880/reviews

Aytaç, S \& Göl, B \& Yücel, F (2014) ‘Nuri Bilge Ceylan’la Kış Uykusu Üzerine. I. II. III', interview with Nuri Bilge Ceylan on winter Sleep, http://www.altyazi.net/soylesiler/nuri-bilge-ceylanla-kis-uykusu-uzerine/

Baudrillard, J (1975) The Mirror of Production. St.Louis: Telos.

Baudrillard, J (1988) America. London: Verso.

Baudrillard, J (2001) Impossible Exchange. London: Verso.

Baudrillard, J (2005) The Intelligence of Evil or the Lucidity Pact. London: Berg.

Baudrillard, J (2005) The Intelligence of Evil or the Lucidity Pact. New York: Berg.

Bauman, Z (1998) 'What Prospects of Morality in Times of Uncertainty', Theory, Society \& Culture, Volume 15(1), pp. 11-22.

Benjamin, W (1996) 'Capitalism as Religion,' in Bullock, M \& Jennings, M W (Eds) Selected Writings. Vol. 1, 1913-1926. Massachusetts: Harvard University Press, pp. 288-291.

Benjamin, W (1999) Illuminations. London: Pimlico.

Bernstein, MA (1992) Bitter Carnival. Ressentiment and the Abject Hero. Princeton: Princeton University Press.

Ceylan in Dawson, T (2007) 'The changing man'. Interview with Nuri Bilge Ceylan, The List, http://www.list.co.uk/article/1603-interview-nuri-bilge-ceylan/

Chekhov, A (2000) 'The Wife', http://www.online-literature.com/anton_chekhov/1261/

Deleuze, G (1994) Difference \& Repetition. London: The Athlone Press. 
Derrida, J (2001) 'Above All, No Journalists', in (Vries, H \& Weber, S (Eds) Religion and Media, Stanford: Stanford University Press, pp. 56-93.

Derrida, J (2002) Acts of Religion. London: Routledge.

Derrida, J (1994) Specters of Marx. London: Routledge.

Feuerbach, L (1989) The Essence of Christianity. New York: Prometheus.

Foucault, M (2001) Fearless Speech. Los Angeles: Semiotex(e).

Gibson, A (2012) Intermittancy. Edinburgh: Edinburgh University Press.

Hamacher, W (2002) 'Guilt History. Benjamin’s sketch “Capitalism as Religion”, Diacritics Vol 32(3-4), pp. 81-106.

Lodge, G (2014) 'The Palme D’or Favorite is a Bloated Disappointment from the Turkish Auteur', http://www.hitfix.com/in-contention/review-nuri-bilge-ceylan-drifts-off-in-talky-trying-wintersleep\#CfRu1gxv3Tb0M2xj.99

Marx, K \& Engels, F (1848) Manifesto of the Communist Party, https://www.marxists.org/archive/marx/works/1848/communist-manifesto/ch01.htm

Marx, K (1975) 'Contribution to the Critique of Hegel's Philosophy of Law. Introduction', in Karl Marx. Frederick Engels. Collected Works. Vol 3. London: Lawrence \& Wishart, pp. 175-87.

Marx, K (1993) Grundrisse. London: Penguin.

Marx, K (2007) Economic and Philosophic Manuscripts of 1844. New York: Dover.

Nietzsche, F (1967) The Will to Power. New York: Vintage.

Nietzsche, F (1996) On the Genealogy of Morals. London: Oxford University Press.

Rancière , J (2010) Dissensus. New York: Continuum.

Ranciere, J (2006) Film Fables, 2006, Oxford: Berg.

Seyirci (2014) 'A masterpiece from one of the greatest film makers of our time', http://www.imdb.com/title/tt2758880/reviews-5

Shakespeare, W (1970) Timon of Athens. In The Complete Works of William Shakespeare. London: Spring Books, pp. 660-683.

Simmel, G (1978) The Philosophy of Money. London: Routledge.

Spinoza, B (1993) Ethics. London: Everyman.

Vries, H de (2005) 'The Two Sources of the "Theological Machine": Jacques Derrida and Henri Bergson on Religion, Technicity, War, and Terror', in C Davis, J Milbank \& S Žižek (Eds) Theology and the Political, USA: Duke University Press, pp. 336-91.

Weber, M (2003) The Protestant Ethic and the Spirit of Capitalism. New York: Dover.

Žižek, S (2009) First as Tragedy, Then as Farce. London: Verso. 